\title{
New wine from old wineskins, a fresh look at Freire
}

Shayne Walker

From these pages I hope at least the following will endure: my trust in people, and my faith in men and in the creation of a world in which it will be easier to love (Freire, 1972, p. 19).

Recently, I re-read Freire's (1972) Pedagogy of the oppressed and found his emphasis on love inspiring. I was left wondering why this is not often quoted regarding Freire. As an educator (University of Otago), regulator (SWRB), whānau worker and supervisor (NGO staff), I believe my work here in Aotearoa New Zealand is about creating contexts within which it is easier to love. I view love broadly as a set of attitudes, actions and thoughts. It produces a professional set of skills that is a personal journey of completion. I am not patient, tolerant or fair all the time, but I should at least try to be. Perhaps love in the context of professional relationships within the social work process is at the heart of a 21st century emancipation and liberation of Māori and other oppressed groups in Aotearoa. Freire understood that treating people as 'fully human' in the social work process was in itself an act of love, otherwise it would be dehumanising.

In this article I will be discussing:

- conscientisation, colonisation, dehumanisation, historical trauma and intergenerational trauma;

- Freire's (1972) notion of a 'culture of silence';

- identity;

- transformative relationships;

- love in social work;

- Freire's virtues and qualities for social workers; and

- fully human practice.

\section{Conscientisation, colonisation, dehumanisation, historical and intergenerational trauma}

A number of theoretical ideas 'lit me up' in 1992 when I started my bachelor's degree at the University of Otago. As Kurt Lewin said 'there is nothing as practical as a good theory' (Lewin \& Cartwright, 1952, p. 169). The theories that provided me with good practice are from Freire's (1972, p. 15) notion of 'conscientisation'. Namely the perception of political, social and economic contradictions, and to take steps against the oppressive elements of that reality, became a mantra for both my thought and practice. It underpinned my approach to human rights, social justice and anti-racist (Thompson, 1997) and anti-oppressive approaches (Dominelli, 2002) within social work. I was, and am, a post-structural social worker who believe[d] we could change the world with Māori and other oppressed groups in our society. My wife Helen and I had spent 12 years of our lives serving young people and their families in various ways, including fostering, whānau work and youthwork. We had chosen this as a vocation and mission through Te Hou Ora which was part of Youth For Christ at the time. We soon discovered that life's outcomes for those we worked with were not just an issue of 'good and evil', but that for Māori in Aotearoa 'colonisation' had long-term impacts and 
still does. We had never heard of 'historical trauma' and 'inter-generational trauma' that were the inheritance of Māori as a result of colonisation (Pihama et al, 2015, 2016). It seems contradictory now, but at the time it made sense to want both 'critical consciousness' and 'salvation' for those we worked with. The church had been both an agent of domination and transformation, so there was not an immediate trust of us and our work, especially by Māori. We had to earn the right in relationships with young people, families and broader communities of interest.

The whānau we worked with have been 'savaged' by decades of neglect and being disenfranchised within their own whenua. While the trauma that has resulted from the processes and actions associated with the colonisation of Māori people in Aotearoa New Zealand continues to be unaddressed, trauma will be transmitted from generation to generation, resulting in a contemporary lifetime trauma, discrimination, chronic stress and in some cases family violence (Pihama et al, 2015, 2016,). In this sense perhaps Māori are better able to resist rather than be resilient. It is almost as if being resilient accepts the trauma inflicted upon Māori is an inevitable outcome of a society that has never accepted Māori as equal (Pihama et al, 2015). Also, trauma grows and is cumulative, in that if a person experiences multiple traumas across time and is unable to process these to a recovery then the ensuing trauma will have a compounding effect on their health and well-being (Rudman et al, 2017).

Dehumanisation through colonisation, although not accepted as concrete historical fact in Aotearoa New Zealand, 'is not a given destiny but the result of an unjust order that engenders violence in the oppressors, which in turn dehumanises the oppressed' (Freire, 1972, p. 21). 'Dehumanisation, which marks those whose humanity has been stolen, but also (though in a different way) those who have stolen it, is a distortion of the vocation of becoming fully human' (Freire, 1972, p. 20). It is perhaps why we have such a high tolerance for violence in our society. In Aotearoa New Zealand the psyche of both Pakeha and Māori is scarred by colonisation. Treaty of Waitangi settlements to some degree deal with nominal compensation, an apology and limited rangatiratanga. But how do we as a society deal with the dehumanisation and its effects on the psyche of both parties? If we are serious about lowering the levels of family violence in Aotearoa New Zealand we have to have a national conversation that acknowleges 'historical and intergenerational trauma'. We have accepted a hegemonic (Gramsci, 1994) view that Māori have chosen to have the worst social statistics in our country and that it is our fault. We must continue to resist this notion and be transformational in our approach in order that our moko have a better life.

The worst part of being 'othered' (Said 1978) is if we believe it and internalise and buy into the inevitability that has apparently been set out before us.

\section{Culture of silence}

Freire's (1972, p. 10) notion of the 'culture of silence', where 'the ignorance and lethargy of the dispossessed are seen as a direct product of the whole situation of economic, social, and political domination - and of paternalism - of which they are victims' (Shaull, 1972, p. 10) made absolute sense to me. We worked with many young people and families who were on the margins who did not desire a critical consciousness regarding their daily reality. The responses to Freire's 'culture of silence' varied, some were violent, some just wanted to be numb with drugs, some threw themselves into sport, others got deeply involved in Te Reo 
and kapa haka etc. They were also susceptible to the invitations of gangs to 'prospect' and we would work hard and use relationships to keep them out of gangs. But gangs were also a 'whānau' that many young people found attractive. I also think they provided an avenue for collective resistance against the 'oppressor', represented by the police and justice system. We would go downtown on Friday and Saturday nights as youth/street workers engaging with young people and trying to provide activity-based alternatives to getting in trouble. We were in a sense both of what Freire (1972) refers to as the rightist sectarian that was trying to 'domesticate the oppressed based on the past' and that of the 'leftist sectarian that accepts a pre-ordained future' (p. 18). Both of these approaches to 'truth' needed challenging so that truth was not given or received but was created by those who needed it, echoing Foucault's (1979) ideas of the productive function of power and knowledge and that truth is the result of 'multiple forms of constraint'. What does this have to do with the transformation of those we worked with? They must discover these truths themselves: as social workers and educators we just provide the context of enabling this process.

The 'culture of silence' was evident in the relationship-making skills of many of the young people we worked with. They often had partners and children while they were still very young. A number of them came to us for help to work on becoming better fathers and partners as they wanted a better life for their children and partners. Many of their stories were horrendous and we marvelled at their ability to survive. One of the key parts of our learning from them was in regards to 'emotional literacy'. When discussing parenting I would ask one of them 'how do you feel about this?' The response was often, 'I would do this', or an expletive that was both positive and negative. We soon realised the language for 'feelings' was often limited or not there. They had not seen it modelled and it certainly wasn't part of their masculinity. So we set up activities (playing with Lego initially) to learn about play and emotional language so that it could become part of their everyday language. The key to changing behaviour was understanding and 'languaging' the 'feeling' that preceded the behaviour. This was some of the best work I have had the privilege of being involved in, as many of these young men escaped this facet of the 'culture of silence' and were able to become better partners and fathers. Every now and then I would come across a young person who had 'dead eyes' at a very young age. There was no shine or sparkle and many of them were 'old' before their time. What had taken the sparkle out of their eyes and how do we work with Māori young people to get it back? (Young, McKenzie, Schjelderup, Omre and Walker, 2014).

\section{Identity}

There is a battle for the restoration and transformation of Māori identity. Adams, Hart, Walker, Mataira, Fleay \& Drew (2017) discuss the cultural practices that are necessary for indigenous well-being. The scars of colonisation are on the inside and they mark the psyche and the soul (Fanon 1968). I think there is more to this than feeling good about 'living in your skin'. The battle is for beauty and dignity that does not transcend colour but is strengthened by it. When I am asked, 'No hea to iwi?' (Where are your bones from?), implicit within the answer is an oral tradition of Maori (indigenous) ways of speaking, knowing and locating. Hauge (2007) has a transactional view of settings, and describes three theories of identity: social-identity, place-identity and identity process approaches (Whitinui, 2013, p. 3). My answer to the above question is 'No Awarua ahau, Ko Kai Tahu, Kati Mamoe, Waitaha, Ngāti Kahungunu oku iwi' (I am located within a place, amongst a people, participating in a language and a 
number of broader cultural constructs that make me a 'fully' cultural human being). The Māori self is located holistically within an integrated, reciprocal set of relationships with people and an environmental context (Hauge, 2007). Our identity is confirmed in the faces of those around us in various ways, I am committed to being Māori, speaking as much Te Reo as I can. Language is not just utilitarian, it has a wairua beyond being functional, it presents cognition, thinking and logic. It is the 'cradle of concepts' (Moll, 1990), therefore using Te Reo by Māori and non-Māori alike is not only an acknowledgement of a particular meaning of a word, but also the thinking of a culture. In this sense, when Te Reo is utilised pedagogically within the social work process with Māori both Gramsci (1994) and Freire (1972) would view it as an act of respect and love. Moving beyond cultural literacy (having knowledge) to cultural fluency (the ability to participate in that culture) (Hirsch, 1987) will enhance the likelihood that Māori identity is restored and strengthened.

I am a flawed human being with many frailties in my character, some of which are connected to my identity as a Māori. The suicides of both my parents when I was 12 scarred me, and, while it did not happen because they were Māori, I did blame Māori culture for not preventing it. I know this is stretching a long bow, but because I was already partially ashamed of my identity as Māori it was easy to blame anything that went wrong in my life on being Māori. At the time I didn't understand that my parents needed people they could discuss their relationship difficulties with, I thought as a child that because they were both Māori, there was obviously something wrong with Māori culture. I am so grateful to those people who knew the right questions to ask, listened to me and modelled the right behaviour for me to follow. Colonisation may be traumatic, and has left its scars on Māori and Pakeha, but it's not the endgame; it is also an opportunity for development and emancipation (Saleeby, 1979). Freire's idea that we should not 'imprison reality' in a 'circle of certainty', but we should confront that reality and radically transform it (p. 18) is alive and well within me in 2017. I see this work as both radical and transformative, as it will have long-term outcomes for whānau Māori.

\section{Transformative relationships}

In our social work teaching and practice we can have functional utilitarian relationships based on case management and key performance indicators (KPIs), or more humane transformative relationships, where, according to Sanborn (2017):

- Instead of 'self-interest' we encourage 'mutual interest';

- Rather than going for 'what you get', you start with 'what you can give';

- Instead of just 'staying in touch', work hard to keep one another 'fully informed';

- Further to having an 'understanding of the process', 'understand the person in the process';

- Don't just 'judge the results', evaluate the relationship;

- 'Winning a conflict' is not as important as 'resolving a conflict';

- Don't just settle with 'agreement', 'acceptance' and 'ownership', give far better long-term results.

- When finally evaluating the results, evaluate how the other feels about the results (Sanborn, 2017).

There are many good guides to achieving transformative relationships. Pa Tate (2010) would encourage us to be tika (correct in our thinking and knowing), pono (having integrity with 
what we know) and aroha (acting out of love). Bishop (2002) would encourage us to become allies by sharing power with, rather than power over. Leland Ruwhiu (2013) would say our practice should be mana-enhancing. Early on in my social work training we would use the term 'unconditional regard'. Dobbs \& Eruera (2014) would encourage the use of cultural imperatives, for example, whakapapa, tikanga, wairua, tapu, mauri and mana, have the potential to inform well-being within a whakawhanaungatanga relationship-making framework. Michael Hart (2015) encourages us to work as indigenist or indigenous, understanding indigenous:

- ways of being in the world;

- values and beliefs;

- theories;

- ways of coming to know;

- practices.

The most influential approach to practising respectful and transformative relationships with Māori has been Maatua Taina Pohatu's (2003) Ngā Takepū (applied principles):

- Āta-haere - proceed with care;

- Āta whakarongo - listening carefully;

- Āta-kōrero- right way of speaking, language appropriate;

- Āta-tuhi - client facts;

- Áta-mahi - working with client;

- Âta-noho - safe places / personal;

- Áta-whakaako - teaching and learning;

- Āta-tohutohu - encourage;

- Âta-kīnaki - net/gather information;

- Āta-hoki mārire - to be successful/good outcome;

- Âta-titiro - looking at specifics / analyse;

- Áta-whakamārama - an indepth understanding.

Maatua Taina Pohatu's work is inspirational and has transformed a number of relationship-making spaces that utilise and extend the principles of takepū. The Family Violence, Sexual Violence and Violence within Whānau Workforce Capability Framework (Rudman et al, 2015) utilises six takepu: Ūkaipō, Rangatiratanga, Whanaungatanga, Aroha, Kaitiakitanga, Manaakitanga and Kotahitanga. The Social Work Registration Board, through the work of the Tangata Whenua Voices in Social Work Roopu, also utilises three takepū within its Kaitiakitanga Framework: Rangatiratanga, Manaakitanga and Whanaungatanga.

Maatua, the mana of your mahi goes forth before you and we thank you!

Transformative relationships acknowledge the mana and rangatiratanga of all of those involved. 'Ko au ko koe, ko koe ko au', 'I am you and you are me', reinforces this notion. Dr Lilla Watson, an Aboriginal activist captures these ideas:

If you have come here to help me then you are wasting your time, but if your liberation is tied to mine, then come, let us work together 


\section{Love in social work}

The Change Factory (Forandringsfabrikken in Norwegian) in Norway is a group of young people who are dedicated to rehabilitating the people in the systems that have worked with them. They are very clear in their requirement that those who work with them must practise in a way that illustrates love: 'I would like it if more of the people in the system showed some warmth and love when they encounter us. I would like them to show more humility, be more open, instead of using well-rehearsed methods and conversation techniques,' says Alexander (Kjellander, Jørgensen, \& Westrum-Rein, 2016, p. 55). Voyce Whakarongo Mai is a similar group set up here in New Zealand as a result of the 2015 Expert Panel Final Report: Investing in New Zealand's Children and Their Families (New Zealand Modernising Child, Youth and Family Expert Panel 2015). Young people who had been in care were key informants to this panel and one of the things they were very clear on was that they wanted people who worked with them to show them love.

The Change Factory (2017) encourage us to have openness, be honest and give enough good information. They also require those who work with them to exhibit humbleness, to have faith in children, to be receptive, respectful and admit mistakes. Love is a must, show us you are committed and show heart warmth. Be cooperative and bring children and young people into the decision making (about their lives) and listen to feedback. We are also encouraged to have warm eyes. Jan Erik Henriksen (2017) would say that to have heart warmth we should have heart language. The Change Factory and Voyce Whakarongo Mai initiatives require us to incorporate love or aroha into our work, and in my view this is critical in a relationship-based profession. Young people are expecting us to be and to treat them as fully human.

\section{Freire's virtues and qualities for social work}

On the 30th of July 1988, Freire gave a seminal keynote address at the Social Workers World Conference, in Stockholm, Sweden, entitled 'A critical understanding of social work'. This paper was translated by Marilyn Moch, and published in 2009. Within the dialogue he shared his thoughts on what it is to be a progressive social worker. In his view, whether it is case work, group work, community work or work in a community organisation, it is inherently substantively educational and pedagogical. Social work practice is not neutral, and is therefore inherently political (Moch, 2009, p. 4). Freire encouraged progressive social workers to have a number of virtues or qualities that we were not given or born with, they are to be nurtured by us in practice.

Firstly, he believed there must be a convergence between what is said and what is done, it is much easier to talk than to do. We must practise what we preach (Moch, 2009, p. 4).

Secondly, Freire (Moch, 2009, p. 5) encouraged us to develop a permanent critical curiosity within ourselves and those we work with. In my view, Freire preferred dialogue and discussion to lecturing as he was critical of the 'banking' concept, where we are considered as empty neutral vessels that receive knowledge and information (banking) and learn accordingly, devoid of context. In his view it was dehumanising. To mitigate against the 'dehumanisation' produced by the banking concept, Freire envisages 'problem-posing education'. In this approach, the roles of students and teachers become less regimented, and both engage in acts of dialogue enrichment to effectively learn from each other. (Micheletti, 
2010). This is similar to the dual nature of ako, where we are both learners and teachers at the same time. We learn in relationships that are agreed upon and have an element of co-design. Then, according to Freire (1972), 'Knowledge emerges only through invention and re-invention, through the restless, impatient, continuing, hopeful inquiry human beings pursue in the world, with the world, and with each other' (p. 46). In regards to child protection and learning, tamariki and whānau are theorists about their own lives (McKenzie, Omre, Schjelderup, Walker, Young, 2014) and must be involved in the co-design, co-construction and meaning-making that emanates from any work done with them (Waldegrave, 2006). The cororally of this is permanent curiosity, in that we are always becoming and our competency is a journey (Moch, 2009, p. 6).

The third virtue or quality which was extraordinarily important to Freire was tolerance. He believed it was the glue that kept us together to fight our common enemy.

His fourth quality was to live with impatient patience. I often ask myself what is the potential of the present, what can we do now? We make history, we, with others, transform our world. In regards to some recent work I have been doing on family violence, we have to believe we can change the social contract we have with violence and make a start, one family at a time. We cannot just wait for this to happen, we must create the context so those we work with discover their own freedom. We cannot give someone freedom of the mind and heart.

Freedom is acquired by conquest, not by gift. It must be pursued constantly and responsibly. Freedom is not an ideal located outside of man; nor is it an idea which becomes myth. It is rather the indispensable condition for the quest for human completion (Freire, 1972, p. 47).

To do this well we must work in a transformative manner that shares power with, rather than over, whānau. All whānau and family have various forms of capital, i.e. narratives, relationships, stories of development and coping, etc (McKenzie et al., 2014).

Fifthly, Freire asks in regards to social work practice, 'What are the limits to my practice?' And those limits are social, political, idealogical and historical (Moch, 2009, p. 7). As Vishanti Sewpaul (2012) would say, 'How are we thinking about our thinking?' and is this limiting my practice?

Lastly, as a mainly intellectual and political exercise, progressive social workers, 'ought to cultivate, to develop, to perfect in their practice an understanding of what is historically possible' (Moch, 2009, p. 7). 'We are in the process of making history and being made by history and this gives us a critical consciousness that is neither critical pessimism nor immobilising fatalism' (Moch, 2009, p. 7). History and life is not outside of us. 'History is made by us and as we make it we are made and remade by it' (Moch, 2009, p. 7).

We are in the process of making relationships and being remade by them. It is within this context that I present some ideas that may assist us in our desire to treat others as fully human.

\section{Fully human practice}

The notion of fully human practice is based on a desire to treat others as fully human, as anything less would dehumanise them. In an age of professional social work it's important 
to emphasise the very human elements that may lead to a transformative relationship. I have always looked for ways that integrate my wairua, hinengaro, tinana and whanau into my practice (Durie, 1998). When you are in the moment, about to undertake a piece of social work with another human being:

- What is your puku (stomach) saying to you? (Physical response: Huata, 2001; Durie, 2012).

- What is your ngakau (heart) saying to you? How have you connected with them and what they are saying and doing? (Felt response: Durie, 2012).

- What is your wairua (spirit) saying to you? (Sensed response: Durie, 2012).

- What does Te Ao Maori/Pakeha matauranga (mind) theory say to you? (Thought response: Durie, 2012).

- What are the whanaungatanga (family making) issues that resonate here? (Relational response: Durie 2012).

- What kind of fabric is being woven? It includes distinctiveness that comes from a number of variants in this cultural context. (Integration response: Durie, 2012, in Young et al.,2014).

This is not an exclusive list or a 'boxed set' that will give you an essentialised model. They are merely a set of questions that encourage you to find your own 'fullness' in terms of the elements that are needed for the people you work with. I encourage you to integrate into your practice the fullness of who you are so that others may discover that for themselves. I am Maori and I cannot leave my ngakau (heart) or wairua (spirit) at the door when I go to work with anyone. The people we work with deserve our fullness of humanity, expressed in a number of ways.

\section{Conclusion}

In social work we must deal with the scars of colonisation and the subsequent dehuminisation and historical and intergenerational trauma that has resulted. This is both a national and personal issue for many young Māori, who may not even know why they feel second-class in their own country or why they are part of such appalling social statistics. Māori are resilient, but perhaps our future is one of resistance as we challenge the 'culture of silence' that has developed over the last 160 years. This does not have to be the 'endgame', and 21st century social work responses must account for structural inequality and the personal responsibility of the people we work with. The 'ignorance and lethargy' are a direct result of paternalism, and are also an opportunity for challenge and development. In social work practice there is a battle for a proud and relevant Maori identity. We must harness the cultural ways of thinking and knowing that enhance Māori identity. Living in 'our own skin' is an identity issue when the view we have in the mirror has been distorted. We are encouraged to move beyond cultural literacy into cultural fluency. This process is to be mediated by aroha or love and young people are requiring us to illustrate love in our practice. This should be seen as a respected professional skill and we should not be afraid of 'heart language' that requires 'warm eyes'.

There are many good guides to transformative relationships. Whether we use mana-enhancing approaches, tika, pono and aroha, or takepu the critical issue is, do we want to share power with others and do we enter the relationship with an open mind that is capable 
of learning from those we work with? Freire's 'banking concept' is as important as ever in our practice and requires us to co-design so that those we work with may find their own freedom. Freire's 1988 six virtues and qualities for progressive social workers are more than relevant today. His advice to us to practise what we preach, develop critical curiosity, to be tolerant, to have impatient patience, to question the limits of our practice and to develop an understanding of what is historically possible.

Fully human practice is not an endpoint in itself, it is a set of questions that are designed to get each of us thinking about how we bring our best to those we work with. We don't turn up to work to be mediocre; our aim is excellence, we are flawed human beings, who on a daily basis get to walk with others as they find their own emancipation and freedom. No matter what our technology or theory is in the future, whakawhānaungatanga (human relationships) will stay at the core of social work and requires us to treat others as fully human.

'Dialogue further requires an intense faith in humankind, faith in their power to make and remake, to create and re-create, faith in their vocation to be more fully human (which is not the privilege of an elite, but the birthright of all)' (Freire 197,p.63)

\section{References}

Adams, M., Hart, M., Walker, S., Mataira, P., Fleay, J.J., \& Drew, N. (2017). Cultural identity and practices associated with the health and wellbeing of indigenous males. ab-Original Journal of Indigenous Studies and First Nations' and First Peoples' Cultures. Pennysylvania Penn State University Press.

Bishop, A. (2002). Becoming an ally: Breaking the cycle of oppression. Canada: Zed Books.

Change Factory. (2017). Erasmus Mundas MFAMILY Program. Stavanger, Norway.

Dobbs, T., \& Eruera, M. (2014). Kaupapa Māori wellbeing framework: The basis for whānau violence prevention and intervention. Issues Paper 6. New Zealand Family Violence Clearing House.

Dominelli, L. (2002). Introducing anti-oppressive theories for practice in anti-oppressive social work: Theory and practice. Basingstoke: Palgrave Macmillan.

Durie, M. (1998). Whaiora Maori Health Development Sec.Ed. Auckland: Oxford University Press.

Durie, M. (2012). Maori concepts of wellbeing: Intervening with Maori children, young people and families. Invercargill: Compass Seminars.

Fanon, F. (1968). The wretched of the Earth (Trans. C. Farington). MacGibbon \& Kee, Penguin.

Foucault, M. (1979). Discipline and punish: The birth of the prison. New York: Vintage Books.

Freire, P. (1972). Pedagogy of the oppressed. England: Penguin Books.

Gramsci, A. (1994). Pre-prison writings. Cambridge: Cambridge University Press.

Hart, M. (2015). From cultural awareness to indigenist practice: Critical perspectives on a spectrum of services, creating a new legacy. Aboriginal Mental Health Conference, Brandon, Manitoba, October 6, 2015.

Hauge, A. L. (2007). Identity and place: A critical comparison of three identity theories. Architectural Science Review, 50(1), 44-51.

Henriksen, J. (2017). From housing campaign to multicultural understanding. The development of professional social work in Sami areas in Norway. Alta 2017, 4th International Indigenous Social Work Conference, 11-14, June Alta, Norway.

Hirsch, E. D., Jr. (1987). Cultural literacy: What every American needs to know. New York: Houghton Mifflan.

Huata, P. (2001). Pōwhiri Poutama, Te Ngaru Learning Systems.

Kjellander, T., Jørgensen, N. B., \& Westrum-Rein, J. (2016). Do rights!: Nordic perspectives on child and youth participation. Nordic Council of Ministers.

Lewin, K., and Cartwright, D. (1952) Field Theory in Social Science: Selected Theoretical Papers by Kurt Lewin. London: Tavistock.

McKenzie, M., Omre, C., Schjelderup, L., Walker, S. \& Young, S. (2014). Child rights / community development principles: Key elements for child protection practice. In S. Hessle (Ed.). Human rights and social equality: Challenges for social work, social work and social development (Vol. 1). England: Ashgate Publishing.

Micheletti, G. (2010). Re-envisioning Paulo Freire's 'Banking concept of education'. Inquiries Journal/Student Pulse, 2(02). Retrieved from http: / / www.inquiriesjournal.com/a?id=171.

Moch, M. (2009). A critical understanding of social work by Paolo Freire. Journal of Progressive Human Services, 20(1), 92-97.

Moll, L. (1990). Vygotsky and education instructional implications and applications of sociohistorical psychology. New York: Cambridge University Press. 
New Zealand Modernising Child, Youth and Family Expert Panel (2015). Expert Panel Final Report: Investing in New Zealand's Children and their Families. Wellington: Ministry of Social Development.

Pihama L., Smith,C., Reynolds, R., Tuhiwai Smith, L., Reid, J., Te Nana, R., (2015). Positioning historical trauma theory within Aotearoa New Zealand. Alternative: An International Journal of Indigenous Peoples, 10(3).

Pihama, L., Te Nana, R., Cameron, N., Smith, C., Reid, J. \& Southey, K. (2016). Māori cultural definitions of sexual violence. Sexual Abuse in Australia and New Zealand, 7(1).

Pohatu, T. W. (2013). Ata: Growing respectful relationships. He Pukenga Korero, 8(1).

Rudman, S., Walker, S., Albert, R,. Ohia R., Smith R., Thurston P., Proudfoot J., Williams B. \& Wansa Harvey, G. (2017). Expert design group for the family violence, sexual violence and violence within whannau workforce capability framework. Wellington: Ministry of Social Development.

Ruwhiu, L. (2013). Making sense of indigenous issues in Aotearoa New Zealand. In M. Connolly \& L. Harms (Eds). Social work contexts and practice, (3rd ed.). Australia New Zealand: Oxford University Press.

Said, E. (1978). Orientalism. New York: Vintage Books.

Saleeby, D. (1997). The strengths perspective in social work.

Sanborn, M. (2017). 9 Differences between Transactional and Relational : how to tell the difference. Retrieved from www. marksanborn.com/free.

Sewpaul, V. (2012). Inscribed in our blood: Confronting the ideology of sexism and racism as possible seeds of liberation and radical change. Joint World Conference on Social Work and Social Development: Action and Impact, Stockholm, Sweden.

Shaull, R. (1972). Forward (pgs 9-14). In P. Freire (Ed.). Pedagogy of the oppressed. England: Penguin Books.

Tate, H. (2010). Towards some foundations of Maori theology. Doctor of Theology, Melbourne College of Divinity.

Thompson, N. (1997) The Theory Base in Anti-discriminatory practice. MacMillan Press, London 15-37.

Waldegrave, C. (2006) Contrasting national jurisdictional and welfare responses to violence to children. Social Policy Journal of New Zealand 27: 57-76.

Watson, L. (no date). Aboriginal activist. Retrieved from http:/ / theblackcard.com.au/\#about-us.

Whitinui, P. (2013). Indigenous autoethnography: Exploring, engaging, and experiencing 'self' as a native method of inquiry. Journal of Contemporary Ethnography, 0891241613508148.

Wilson, L. (no date). Aboriginal activist. Retrieved from http:/ / theblackcard.com.au/\#about-us.

Young, S., McKenzie, M., Omre, C., Schjelderup, L., \& Walker, S. (2014). Practicing from Theory: Thinking and knowing to 'do' child protection work. Social Sciences, 3, 893-915.

Young, S., McKenzie, M., Schjelderup, L., Omre, C., \& Walker, S. (2014). What can we do to bring the sparkle back into this child's eyes? Child rights/community development principles: Key elements for a strengths-based child protection practice. Child Care in Practice 20(1): 135-152. 